\title{
НАНОЧАСТИНКИ ОКСИДУ ЦИНКУ ПОСИЛЮЮТЬ ГЕПАТОТОКСИЧНИЙ ЕФЕКТ ГЕРБІЦИДУ ГЛІФОСАТУ
}

Вступ. Наноматеріали стали причиною справжнього прориву в багатьох галузях і проникають у всі ссрери нашого життя. Завдяки унікальним властивостям наночастинки оксиду цинку широко використовують у промисловості та медицині. Однак при повсякденному зростанні темпів застосування наноматеріалів усе менше уваги приділяють можливому негативному впливу наночастинок на безпеку навколишнього середовища та на здоров'я людей у цілому. Здатність наночастинок здійснювати транспортування лікарських засобів та хімічних речовин усередину клітини робить актуальним питання про потенційну можливість посилення токсичної дії класичних токсикантів при їх сумісному надходженні в організм з наночастинками.

Мета дослідження - вивчити вплив наночастинок оксиду цинку на гепатотоксичний ефект гербіциду гліфосату.

Методи дослідження. Досліди виконано на безпородних щурах-самцях, яким внутрішньошлунково протягом 14-ти днів вводили у вигляді суспензії 0,5 мл наночастинок оксиду цинку в дозі 100 мг/кг та гліфосат (у фрормі гербіциду раундапу) в дозі 250 мг/кг маси тіла. Для проведення експерименту тварин поділили на 4 групи: 1-ша - контрольна (інтактні щури); 2-га - тварини, яким вводили наночастинки оксиду цинку; 3-тя - щури, уражені гербіцидом гліфросатом; 4-та - тварини, яким вводили наночастинки оксиду цинку разом із гліфросатом. Токсиканти вводили сумісно та окремо. У сироватці крові визначали активність аланін- і аспартатамінотрансфрераз, лужної фросфратази, вміст загального протеїну та сечовини.

Результати й обговорення. Встановлено, що під впливом наночастинок оксиду цинку достовірно підвищувалася лише активність аланін- і аспартатамінотрансфрераз. Введення щурам гербіциду гліфросату призводило до виражених змін усіх досліджуваних показників. Максимальні їх зміни зареєстровано у групі тварин, яким сумісно вводили наночастинки та гліфросат. У цьому випадку активність амінотрансфрераз і лужної фросфратази змінювалася достовірно порівняно з аналогічними показниками у групі щурів, яким вводили тільки гербіцид.

Висновок. Наночастинки оксиду цинку здатні посилювати гепатотоксичний ефрект глісросату.

КЛЮЧОВІ СЛОВА: наночастинки оксиду цинку; гербіцид гліфосат; гепатотоксичність.

ВСТУП. Сьогодні розвиток нанотехнологій швидко просувається практично в усіх сорерах нашого життя. Сучасні технології дедалі більше орієнтуються на використання наноматеріалів у різних галузях виробництва, медицині, фрармації. До найпоширеніших промислових наноматеріалів, з якими найчастіше контактують живі організми, належать наночастинки оксиду цинку (нано-ZnO) [1-3]. Завдяки особливим фрізичним та хімічним властивостям нано-ZnO широко використовують у різних галузях, наприклад у виробництві різних барвників, кераміки, фоотокаталізаторів, у комерційних продуктах, таких, як сонцезахисні креми та засоби повсякденного (с Я. Ю. Гапоненко, Н. Я. Летняк, М. М. Корда, 2019. догляду. Крім цього, наночастинки застосовують у харчовій промисловості та сільському господарстві, а також у медицині як протимікробний і протигрибковий засіб [4, 5]. За останні два десятиліття нано-ZnO стали найпопулярнішим наноматеріалом оксиду металу в плані біологічного використання завдяки їх чудовій біосумісності, економічності та відносно низькій токсичності [6-8].

Різке збільшення обсягу виробництва в усьому світі ряду наноматеріалів неминуче призведе до надходження значної їх кількості в довкілля, накопичення в компонентах біоти й абіотичних середовищах з подальшою можливою передачею людині. Тому швидкий прогрес новітніх 
технологій не лише відкриває широкі перспективи для використання наноматеріалів у всіх сорерах діяльності людини, але й викликає велике занепокоєння у зв'язку з їх потенційним ризиком для здоров'я людини та навколишнього середовища [8-10]. Крім того, за умов масового антропогенного навантаження на екосистеми наноматеріали впливають на організм людини не лише ізольовано, а й у поєднанні 3 великим числом різних речовин хімічної природи, які є контамінантами об'єктів довкілля, зокрема гербіцидами широкого спектра дії. Тому, враховуючи інтенсивний розвиток нанотехнологій, зокрема широке використання нано-ZnO в різних галузях промисловості, необхідно дослідити як їх безпосередній токсичний вплив на біологічні системи, так і механізм їх дії при сумісному застосуванні 3 найбільш поширеними хімічними речовинами.

Гербіцид гліфросат малотоксичний для ссавців, однак багаторічне і неконтрольоване його використання для обробки сільськогосподарських культур призвело до забруднення ґрунтів водойм та потрапляння гліфосату і його метаболітів з продуктами харчування в організм людини.

Мета дослідження - вивчити вплив наночастинок оксиду цинку на гепатотоксичний ефект гербіциду гліфосату.

МЕТОДИ ДОСЛІДЖЕННЯ. В експерименті використовували безпородних щурів-самців масою 160 г, яких утримували на стандартному раціоні віварію. Інтоксикацію в щурів моделювали шляхом щоденного внутрішньошлункового введення їм упродовж 14-ти діб у вигляді суспензії 0,5 мл наночастинок оксиду цинку в дозі 100 мг/кг [11] і гліфосату (у фрормі гербіциду раундапу) в дозі 250 мг/кг маси тіла. Токсиканти вводили сумісно та окремо. Як контроль використовували інтактних тварин, яким вводили питну воду.

Диспергування наночастинок у воді чи розчині гліфросату проводили за допомогою ультразвукового диспергатора УЗДН-М750Т (20-25 кГц, 750 Вт) протягом 5 хв.

Усіх піддослідних тварин поділили на 4 групи: 1-ша - контрольна (інтактні щури); 2-га - тварини, яким вводили наночастинки оксиду цинку; 3-тя - щури, уражені гербіцидом глісросатом; 4-та - тварини, яким вводили наночастинки оксиду цинку разом із гліфосатом. Щурів виводили з експерименту на 15-ту добу під тіопентал-натрієвим наркозом (40 мг/кг маси тіла тварини).

У сироватці крові визначали активність аланінамінотранссрерази (АлАТ), аспартатамі- нотрансфрерази (АсАТ), лужної фросфратази (ЛФ), вміст загального протеїну та сечовини загальноприйнятими методами на напівавтоматичному аналізаторі HUMALYZER 2000 з використанням стандартних наборів реагентів фрірми "Human" (Німеччина). В експерименті застосовували нанопорошок ZnO виробництва "USResearch Nanomaterials, Inc." (США).

Статистичну обробку цифрових даних здійснювали за допомогою програмного забезпечення STATISTICA 6.0 з використанням непараметричних методів оцінки одержаних даних. Для всіх показників розраховували значення середньої арисрметичної вибірки (М), її дисперсії і помилки середньої (m). Достовірність різниці значень між незалежними кількісними величинами встановлювали за допомогою критерію Манна - Уїтні. Зміни вважали статистично достовірними при $p<0,05$.

РЕЗУЛЬТАТИ Й ОБГОВОРЕННЯ. ЯК ПоКаЗали результати наших досліджень, двотижневе введення щурам суспензії наночастинок оксиду цинку в дозі 100 мг/кг супроводжувалось змінами активності в сироватці крові ензимів маркерів цитолізу - АлАТ і АсАТ. Зокрема, активність АлАТ збільшувалася в 1,4 раза $(p<0,05)$ порівняно 3 показником контрольної групи тварин, а активність АсАТ після введення наночастинок зростала в 1,3 раза $(p<0,05)$. Спостерігали також тенденцію до підвищення активності ЛФ, проте такі зміни виявилися статистично недостовірними.

Слід зазначити, що під впливом наночастинок оксиду цинку здатність гепатоцитів до синтезу протеїну й азотовмісних продуктів суттєво не змінювалася (вміст загального протеїну та сечовини в сироватці крові щурів, яким вводили наночастинки оксиду цинку, достовірно не відрізнявся від такого у тварин контрольної групи).

На відміну від групи щурів, які отримували наночастинки оксиду цинку, внутрішньошлункове введення гліфосату призводило до вираженого порушення фрункцій гепатоцитів. Про це, зокрема, свідчило достовірне зростання активності маркерів цитолізу: АлАТ - в 1,8 раза $(p<0,05)$, AсAT - в 1,7 раза $(p<0,05)$ порівняно 3 контрольною групою тварин. Підвищення активності в сироватці крові даних ензимів $€$ результатом порушення цілісності мембран гепатоцитів і надійним індикатором гострих уражень печінки.

На ураження печінки досліджуваним токсикантом також вказувало виражене підвищення активності ЛФ. На 15-ту добу експерименту активність ензиму зростала в 1,5 раза $(p<0,05)$ порівняно з відповідним показником у групі інтактних тварин. Під впливом гербіциду спосте- 
рігали також достовірне зменшення вмісту загального протеїну (на 28 \% порівняно з показником у щурів контрольної групи) і рівня сечовини (на $27 \%$ в в сироватці крові.

Максимальні зміни біохімічних показників функціонального стану печінки зафіксовано в щурів, яким одночасно вводили гліфросат та наночастинки оксиду цинку (табл.). У них спостерігали достовірні зміни всіх досліджуваних показників відносно інтактних тварин. Активність аланінамінотрансорерази перевищувала показник норми у 2,2 раза ( $<<0,05)$, аспартатамінотрансорерази - у 2,1 раза $(p<0,05)$, лужної фоссратази - в 1,8 раза ( $<<0,05)$. Під впливом комбінованої дії наночастинок та глісосату достовірно змінювалася здатність гепатоцитів синтезувати протеїни й азотовмісні продукти порівняно з інтактними тваринами.

Таблиця - Вплив наночастинок оксиду цинку та гліфосату на показники функціонального стану печінки ( $\mathrm{M} \pm \mathrm{m}, \mathrm{n}=8)$

\begin{tabular}{|c|c|c|c|c|}
\hline \multirow{2}{*}{ Показник } & \multicolumn{4}{|c|}{ Група тварин } \\
\hline & інтактні & нано-ZnO & гліфосат & нано-ZnO+гліфосат \\
\hline \multicolumn{5}{|c|}{ Сироватка крові } \\
\hline АлАТ, Од/л & $56,32 \pm 2,05$ & $76,03 \pm 3,12^{*}$ & $101,37 \pm 3,95^{\star}$ & $128,40 \pm 5,32^{\star \#}$ \\
\hline АсАТ, Од/л & $145,13 \pm 11,85$ & $185,76 \pm 12,19^{*}$ & $243,81 \pm 15,96^{*}$ & $304,77 \pm 20,11^{\text {*\# }}$ \\
\hline ЛФ, Од/л & $258,54 \pm 16,22$ & $291,35 \pm 17,34$ & $374,88 \pm 20,35^{*}$ & $478,29 \pm 23,05^{\star \#}$ \\
\hline Загальний протеїн, г/л & $72,08 \pm 3,42$ & $63,21 \pm 3,09$ & $56,33 \pm 3,05^{\star}$ & $48,62 \pm 2,75^{\star}$ \\
\hline Сечовина, ммоль/л & $5,91 \pm 0,55$ & $4,83 \pm 0,46$ & $4,32 \pm 0,40^{*}$ & $3,46 \pm 0,35^{*}$ \\
\hline
\end{tabular}

Примітки:

1. * - зміни достовірні порівняно з контролем $(p<0,05)$.

2. * - зміни достовірні порівняно з групою тварин, яким вводили гліфосат $(p<0,05)$.

Слід зазначити, що у тварин 4-ї групи активність маркерних ензимів цитолізу та лужної оросоратази була достовірно вищою порівняно зі щурами, яким вводили гербіцид без наночастинок. На вміст загального протеїну та сечовини в сироватці крові сумарне застосування наночастинок і гліфосату достовірного ефекту, порівняно 3 впливом тільки токсиканта, не справило.

3 огляду на такі результати, можна зробити висновок, що здатність фросфорорганічного гербіциду гліфосату проявляти гепатотоксичний есрект достовірно зростає при його сумісному введенні з наночастинками оксиду цинку. Наночастинки та гліфосат взаємодіють синергічно в плані індукції цитолітичного ушкодження печінки, що проявляється, зокрема, інтенсивнішим виходом у кров амінотрансфераз і лужної фосоратази.

\section{СПИСОК ЛІТЕРАТУРИ}

1. Лахтин В. М. Нанотехнологии и перспективы их использования в медицине и биотехнологии / В. М. Лахтин, С. С. Афранасьев, М. В. Лахтин // Вестн. PAMH. - 2008. - № 4. - C. 50-55.

2. Микитюк М. В. Наночастинки та перспективи їх застосування в біології і медицині / М. В. Микитюк // Проблеми екології та медицини. - 2011. - № 5-6. C. 41-49.

3. Трахтенберг І. М. Наночастинки металів, методи отримання, сорери застосування, фрізико-хімічні та токсичні властивості / І. М. Трахтенберг, Н. М. Дмитру-
Найбільш імовірним поясненням вказаного синергізму токсичності досліджуваних чинників може бути ефрект посилення біодоступності гліфосату, що зумовлено здатністю наночастинок зв'язувати на своїй поверхні токсин та сприяти його полегшеному транспортуванню до тканин і клітин.

ВИСНОВОК. Наночастинки оксиду цинку здатні посилювати гепатотоксичний ефект гліфросату. Механізм такого синергічного ефекту гербіциду і наночастинок потребує подальшого дослідження.

Перспективи подальших досліджень. Для безпечного використання нанотехнологій необхідні подальші біохімічні дослідження, спрямовані на вивчення механізмів синергічного впливу наночастинок і гербіцидів на організм. 
проблеми оцінки їхнього небезпечного впливу на живі організми (огляд літератури) / Н. С. Леоненко, О. В. Демецька, О. Б. Леоненко // Сучасні проблеми токсикології, харчової та хімічної безпеки. - 2016. - № 1. C. $64-77$.

7. Цинк і наноцинк: властивості, застосування у клінічній практиці / І. С. Чекман, 3. Р. Ульберг, А. Д. Руденко [та ін.] // Укр. мед. часоп. - 2013. - № 2 (94). III/IV. - C. 42-47.

8. Wang B. Acute toxicological impact of nano- and submicroscaled zinc oxide powder on healthy adult mice / B. Wang, W. Feng, M. Wang et al. // Journal of Nanoparticle Research. - 2008. - 10 (2). - P. 263-276.

\section{REFERENCES}

1. Lakhtin, V.M., Afanasev, S.S., \& Lakhtin, M.V. (2008). Nanotekhnologii i perspektivy ikh ispolzovaniya $\checkmark$ meditsine i biotekhnologii [Nanotechnology and the prospects for their use in medicine and biotechnology]. Vestn. RAMN - Bulletin of the RAMS, 4, 50-55 [in Russian].

2. Mykytiuk, M.V. (2011). Nanochastynky ta perspektyvy yikh zastosuvannia v biolohii i medytsyni [Nanoparticles and prospects for their application in biology and medicine]. Problemy ekolohii ta medytsyny - Problems of Ecology and Medicine, 5-6, 41-49 [in Ukrainian].

3. Trakhtenberh, I.M., \& Dmytrukha, N.M. (2013). Nanochastynky metaliv, metody otrymannia, sfery zastosuvannia, fizyko-khimichni ta toksychni vlastyvosti [Metal nanoparticles, production methods, applications, physicochemical and toxic properties]. Ukrainskyi zhurnal z problem medytsyny pratsi - Ukrainian Journal on Problems of Occupational Medicine, 4 (37), 62-74 [in Ukrainian].

4. Heera, P. (2015). Nanoparticle characterization and application: an overview. Int. J. Curr. Microbiol. App., 4 (8), 379-386

5. Jiang, J., \& Cai, J. (2018). The advancing of zinc oxide nanoparticles for biomedical applications. Bioinorganic Chemistry and Applications. Article ID 1062562, 18 pageshttps://doi.org/10.1155/2018/1062562.

6. Leonenko, N.S., Demetska, O.V., \& Leonenko, O.B. (2016). Osoblyvosti fizyko-khimichnykh vlastyvostei ta toksychnoi dii nanomaterialiv - do problemy otsinky yikhnoho nebezpechnoho vplyvu na zhyvi orhanizmy (ohliad literatury) [Features of physicochemical properties
9. Jones $\mathrm{N}$. Antibacterial activity of $\mathrm{ZnO}$ nanoparticle suspensions on a broad spectrum of microorganisms / N. Jones, B. Ray, K. T. Ranjit et al. // FEMS Microbiol. Lett. - 2008.- 279 (1). - P. 71-76.

10. Silva E. Da. Jensen Interaction of biologically relevant proteins with $\mathrm{ZnO}$ nanomaterials: Aconfounding factor for in vitro toxicity endpoints. / E. Da. Silva, Y. Kembouchea, U. Tegnera, A. Baunb, A. Keld // Toxicology in Vitro. - 2019. - 56. - P. 41-51.

11. Howaida N. Oral exposure to zinc oxide nanoparticles induced oxidative damage, inflammation and genotoxicity in rat's lung / N. Howaida, H. Atti, M. Shalaby, M. Arafah // Life Science Journal. - 2013. - 10 (1). P. 1969-1979. and toxic action of nanomaterials - to the problem of estimation of their dangerous impact on living organisms (literature review)]. Suchasni problemy toksykolohii, kharchovoi ta khimichnoi bezpeky - Modern Problems of Toxicology, Food and Chemical Safety 1, 64-77 [in Ukrainian].

7. Chekman, I.S., Ulberh, Z.R., Rudenko, A.D., Marushko, Yu.V., Hruzina, T.H., Reznichenko, L.S., Dybkova, S.M., \& Hrebelnyk A.I. (2013). Tsynk i nanotsynk: vlastyvosti, zastosuvannia u klinichnii praktytsi [Zinc and nano zinc: properties, application in clinical practice]. Ukr. med. Chasopys - Ukrainian Medical Herald, 2 (94, III/IV, 42-47 [in Ukrainian].

8. Wang, B., Feng, W., \& Wang, M. (2008). Acute toxicological impact of nano- and submicroscaled zinc oxide powder on healthy adult mice. Journal of Nanoparticle Research, 10 (2), 263-276.

9. Jones, N., Ray, B., \& Ranjit, K.T. (2008). Antibacterial activity of $\mathrm{ZnO}$ nanoparticle suspensions on a broad spectrum of microorganisms. FEMS Microbiol. Lett., 279 (1), 71-76.

10. Silva, E. Da., Kembouchea, Y., Tegnera, U., Baunb, A., \& Keld, A. (2019). Jensen Interaction of biologically relevant proteins with $\mathrm{ZnO}$ nanomaterials: Aconfounding factor for in vitro toxicity endpoints. Toxicology in Vitro, 56, 41-51.

11. Howaida, N., Atti, H., Shalaby, M., \& Arafah, M. (2013). Oral exposure to zinc oxide nanoparticles induced oxidative damage, inflammation and genotoxicity in rat's lung. Life Science Journal, 10 (1), 1969-1979.

Я. Ю. Гапоненко, Н. Я. Летняк, М. М. Корда ТЕРНОПОЛЬСКИЙ НАЦИОНАЛЬНЫЙ МЕДИЦИНСКИЙ УНИВЕРСИТЕТ ИМЕНИ И. Я. ГОРБАЧЕВСКОГО МОЗ УКРАИНЫ

\section{НАНОЧАСТИЦЫ ОКСИДА ЦИНКА УСИЛИВАЮТ ГЕПАТОТОКСИЧЕСКИЙ ЭФФЕКТ ГЕРБИЦИДА ГЛИФОСАТА}

\section{Резюме}

Вступление. Наноматериалы стали причиной настоящего прорыва во многих отраслях и проникают во все сореры нашей жизни. Благодаря уникальным свойствам наночастицы оксида цинка широко используют в промышленности и медицине. Однако при обычном росте темпов применения наномате- 
риалов все меньше внимания уделяют возможному негативному влиянию наночастиц на безопасность окружающей среды и на здоровье людей в целом. Способность наночастиц осуществлять транспортировку лекарственных средств и химических веществ внутрь клетки делает актуальным вопрос о потенциальной возможности усиления токсического действия классических токсикантов при их совместном поступлении в организм с наночастицами.

Цель исследования - изучить влияние наночастиц оксида цинка на гепатотоксический эфрфект гербицида глифросата.

Методы исследования. Опыты выполнены на беспородных крысах-самцах, которым внутрижелудочно в течение 14-ти дней вводили в виде суспензии 0,5 мл наночастиц оксида цинка в дозе 100 мг/кг и глифросат (в фрорме гербицида раундапа) в дозе 250 мг/кг массы тела. Для проведения эксперимента животных разделили на 4 группы: 1-я - контрольная (интактные крысы); 2-я - животные, которым вводили наночастицы оксида цинка; 3-я - крысы, пораженные гербицидом глифросатом; 4-я - животные, которым вводили наночастицы оксида цинка вместе с глифросатом. Токсиканты вводили совместно и по отдельности. В сыворотке крови определяли активность аланин- и аспартатаминотранссрераз, щелочной фросфратазы, содержание общего протеина и мочевины.

Результаты и обсуждение. Установлено, что под влиянием наночастиц оксида цинка достоверно повышалась только активность аланин- и аспартатаминотрансфераз. Введение крысам гербицида глиоросата приводило к выраженным изменениям всех исследуемых показателей. Максимальные их изменения зарегистрированы в группе животных, которым совместно вводили наночастицы и глифоосат. $B$ этом случае активность аминотрансфрераз и щелочной фросфратазы менялась достоверно по сравнению с аналогичными показателями в группе крыс, которым вводили только гербицид.

Вывод. Наночастицы оксида цинка способны усиливать гепатотоксический эфффект глифосата.

КЛЮЧЕВЫЕ СЛОВА: наночастицы оксида цинка; гербицид глифосат; гепатотоксичность.

Ya. Yu. Haponenko, N. Ya. Letniak, M. M. Korda I. HORBACHEVSKY TERNOPIL NATIONAL MEDICAL UNIVERSITY

\section{ZINC OXIDE NANOPARTICLES ENHANCE THE HEPATOTOXIC EFFECTS OF GLYPHOSATE HERBICIDE}

\section{Summary}

Introduction. Nanomaterials have caused a step forward in many industries and are used in our overall life. Due to their unique properties, zinc oxide nanoparticles are widely used in industry and medicine. The ability of nanoparticles to transport drugs and chemicals inside the cell makes the question actual of the potential ability to enhance the toxic action of classic toxicants when entering the body simultaneously with nanoparticles.

The aim of the study - to investigate the effect of zinc oxide nanoparticles on the hepatotoxic effects of glyphosate herbicide.

Research Methods. The experiments were carried out on outbred male rats, which were injected intragastrically $0.5 \mathrm{ml}$ of ZnO nanoparticles at a dose of $100 \mathrm{mg} / \mathrm{kg}$ and glyphosate (in the form of herbicide roundup) at a dose of $250 \mathrm{mg} / \mathrm{kg}$ of body weight in the form of suspension during 14 days. The experimental animals were divided into 4 groups: group 1 - the control (intact rats), group 2 - the rats administered with ZnO nanoparticles, group 3 - the animals administered with glyphosate, group 4 - the rats administered with the suspension of ZnO nanoparticles+ glyphosate. The toxicants were administered simultaneously and separately. The activity of alanine- and aspartate aminotransferases, alkaline phosphatase, total protein and urea content were determined in serum.

Results and Discussion. It was concluded that under the influence of zinc oxide nanoparticles only the activity of alanine- and aspartate aminotransferases was significantly increased. The administration of glyphosate herbicide led to marked changes in all the studied parameters. Maximum changes were recorded in the group of animals which were administered nanoparticles and glyphosate simultaneously. In this case, the activity of aminotransferases and alkaline phosphatase was significantly changed compared to similar parameters in the group of animals that were administered only herbicide.

Conclusion. Zinc oxide nanoparticles are able to enhance the hepatotoxic effect of glyphosate.

KEY WORDS: zinc oxide nanoparticles; glyphosate herbicide; hepatotoxicity.

Отримано 25.10.19

Адреса для листування: Н. Я. Летняк, Тернопільський національний медичний університет імені І. Я. Горбачевського МОз України, майдан Волі, 1, Тернопіль, 46001, Україна, e-mail: letnyak@tdmu.edu.ua. 